\title{
DETERMINANTS OF FERTILIZER USE AMONG SMALL-HOLDER FARMERS IN WETLAND REGION OF CROSS RIVER STATE.
}

S. B. AKPAN and A. E. AYA

(Received 19 January, 2009; Revision Accepted 5 October, 2009)

\begin{abstract}
The study modelled and estimated the fertilizer demand function for wetland farmers in Cross River State. Stratified random sampling method was used to collect cross sectional data from 130 wetland farmers with the help of a well structured questionnaire and personal interview schedules. Ordinary Least Squares Method was used to estimate the specified equation. The results reveal that household size, household consumption expenditure, number of poultry birds kept by farmers, number of goats owned and perceived price of fertilizer have negative effect on fertilizer demand. Education of the farmer, farm size, extension agent contact, farm income, ability to predict rainfall, modern communication facilities, output of maize and mixed cropping in combination with maize have positive influence on fertilizer demand. Also policies that reduce production constraints and household size were recommended. In addition, policies that strengthen the present extension programme and improve rural infrastructures would help to reduce production cost while increasing fertilizer demand and farmers wellbeing.
\end{abstract}

KEY WORD: Fertilizer, Wetland, Farmer, Demand, Policy

\section{INTRODUCTION}

Nigeria depends so much on the agricultural sector. The sector employs more than $70 \%$ of the active population, provides raw materials for agro-based industries; it is also a good source of fuel and, most important, reliable source of food to our teeming population (Okunneye 2003 and Lawal 2008). The present government has identified the immense contribution of the agricultural sector to Nigeria's economic development. Though in recent years, the country has witnessed a remarkable improvement in the growth rate (about 5\%) of agricultural sector compared to less than $2 \%$ growth rate of the 1980's (Falusi, 2008), Nigeria is yet to adequately feed its citizens. The country relies mostly on heavy food importation, especially the grains. Growth in the agricultural sector has remained unsatisfactory given the low level of innovations among our farmers (Abdulahi, 1999 and Uwatt, 1997). Therefore, for the country to successfully satisfy the increasing food demand of her population, agricultural productivity must increase. In Nigeria, the recent improvement in agricultural growth rate has been attributed to hectarage expansion rather than actual improvement in farm management techniques (Falusi, 2008). With increased population pressure, farms in upland and wetland regions of the country are under intense usage (Kelly, 2006). This has altered some of the farming practices such as fallowing system, shifting cultivation and crop rotation. Rather farmers now adopt intensive land cultivation technique and drastic reduction in the fallowing period, which has a declining effect on soil fertility, especially in soil erosion prone southern part of the country.

To tackle this problem of decreasing soil fertility and unsatisfactory agricultural output, there is an overwhelming need to intensify the use of fertilizer technology among our farmers. Empirical studies have shown that chemical or mineral fertilizer is one of the most powerful productivity enhancing inputs available (Naseem et al 1999; Byerlee et al 1997; Heisey 1997). Nigerian farmers consumed on the average $11.8 \mathrm{~kg}$ per hectare of fertilizer between 1991 and 1995. The figure declined to $8.9 \mathrm{~kg}$ per hectare in 1996 and later increased to $9 \mathrm{~kg} / \mathrm{ha}$ in 2002 to 2003 (Gruhn et al 2000; FAO 2004 and FAO, 2004b). The government subsidy programme on fertilizer input did not significantly affect fertilizer consumption among smallholder farmers (Smith et al 1994; Daramola 1986 and Nwosu, 1995).

At the state level, various state governments have mapped out several strategies to increase fertilizer consumption among her farmers through direct procurement and extension services. In Cross River State, in particular, government has been involved in direct distribution of fertilizer to farmers through Local Government Liaison Offices. The state has two distinct ecological zones: the dry inland area and the coastal wetland region. The wetland area stretches from Akpabuyo Local Government Area through Calabar South and Calabar Municipality to Odukpani Local Government Area. Also there are some spotted wetlands along Ikom River and Calabar River. The wetland stretches inland for a distance of $25 \mathrm{~km}$ from the Atlantic Ocean and comprising inshore waters, coastal lagoons, estuaries and mangrove swamp (Awosika et al 2001). The rainy season spans the period, April to October, with an annual rainfall of $3000 \mathrm{~mm}$ to $4000 \mathrm{~mm}$. The dry season lasts between November and March (Awosika, 2001b). This unique demarcation makes farming more lucrative in the upland area during rainy season. The wetland region offers an opportunity for allyear crop farming including the dry season.

Wetland crop farming in Cross River State has been going on for ages. This practice has turned up 
several tons of agricultural output especially the shortlive crops like okra, maize, rice, improved hybrid of cassava, cucumber, cocoyam, pumpkin among others. Due to encroachment of human development the area has been under intensive year to year cultivation with a corresponding reduction in farms size and soil fertility. To cope with increasing demand for food especially during the dry season and rapidly increasing population of the state there is an overwhelming need to improve on the existing manure based soil improvement technique of the wetland farmers in the state. Mineral fertilizers technology is crucial to such efficiency. With the current effort by the Cross River State Government towards fertilizer distribution and extensive publicity on the use of mineral fertilizer, farmers are ready to buy and use mineral fertilizers in the wetland region. Since these fertilizers are not free; the pertinent question becomes; what factors affect wetland farmers in buying this farm input? The identification of these factors would help to address the constraint wetland farmers have in consuming mineral fertilizer. This, it is hoped, would help to lessen the food problem and reduce the scourge of urban and rural poverty among the citizens of the state.

The study will therefore specifically attempt to identify the determinants of fertilizer use or demand among wetland farmers of Cross River State. The study will also assess the socio-economic characteristics of the wetland farmers as well as highlight policy implication of our findings for appropriate recommendations.

\section{LITERATURE REVIEW}

Kelly (2006), while studying factors affecting demand of fertilizer in sub-Saharan Africa, identified price of fertilizer, output price of crops, and prices of other inputs that substitute for fertilizer including parameter of fertilizer production function as factors affecting fertilizer demand in the region. Staal et al (2003), identify education, extension service, number of adults per acre, cash crop plot, pasture plot, idea or prediction of rainfall pattern by farmers, population density and various soil textures (clay, loamy and sand) as important determinants of fertilizer demand decision in Kenya. Fufa et al (2006) on their empirical research on determinants of fertilizer use on Maize farms in eastern Ethiopia found out that age and farmers perception and the current price is high have a negative significant effect on fertilizer demand among farmers. They also highlighted farmer's expectation of good rainfall season to have positive significant effect on fertilizer demand. On the other hand, Croppenstedt et al (1996) in their work on the determinants of demand of fertilizer among cereal farmers in Ethiopia found plot size, previous experience with fertilizer, supply of fertilizer, liquidity, oxen owned by household, and the ratio of price of main crop to cost of fertilizer and credit availability as important factors constraining fertilizer demand. Naseem et al (1999) also identified factors affecting fertilizer use in sub-Saharan Africa to include farm size, amount of rainfall, density of road infrastructure, household size and percentage of land devoted to cotton. Minot et al (2000) studied demand of fertilizer among farmers in Benin Republic and Malawi and found out in Benin Republic that education of household head, size of farm plot, and household head expenditure have a positive significant effect on fertilizer demand, while farm size squared, maize plot, rice plot, number of cattle owned, and number of oxen have a negative significant effect on fertilizer demand among farmers. In Malawi, however, they inferred that unit household size, education of household head, ethnicity, price of maize, farm size, number of pigs owned, household head expenditure, club membership, vegetable plot, tobacco plot and maize plot have positive significant effect on fertilizer demand. Plot ownership, regions and size of the plot on the other hand have negative significant effect on fertilizer demand.

\section{THEORETICAL AND MATHEMATICAL FRAMEWORK}

The study is based on the concept of profit $(\pi)$ maximization. We assume that a farmer is a rational producer and decision maker. A wetland farmer is assumed to face an optimization problem such that profit is maximized with respect to the cost of variable production inputs. Let us consider a farmer that wants to maximize profit of $Y$ output crop given inputs $X_{1}, X_{2}$, and input normalized prices of $r_{1}$ and $r_{2}$ respectively. Also the output price is given as $P$.

Then $\pi=P Y-r_{1} x_{1}-r_{2} x_{2} \ldots \ldots \ldots \ldots . . .(1)$

To optimize equation (1) involves maximizing $\pi$ subject to cost constraint.

Maximize $\pi=P Y-r_{1} x_{1}-r_{2} x_{2} \ldots \ldots \ldots$ (2)

Subject to

$C^{0}=r_{1} x_{1}+r_{2} x_{2}$

$\mathrm{C}^{0}$ is a constant cost of inputs used in producing $\mathrm{Y}$. This cost is a constraint that limits the farmer's ability to obtain more inputs. Hence $Y=f\left(x_{1}, x_{2}\right)$ and the relationship is ideally concave. Following the above condition we can specify various forms of production technology models. We consider Ordinary Least Squares method (OLS) instead of Maximum Likelihood Method. This is because we assume that the error term exhibits all the characteristics assumed by OLS method. Through extensive publicity, the farmers are assumed to have good knowledge of the availability of the fertilizer but are constrained by certain factors in purchasing the input. Therefore the shape of the error distribution is assumed to be symmetry as only few farmers would be expected to have no idea of the availability of fertiliser. The normal or symmetry shape of the error term validates the use of OLS instead of the Maximum Likelihood Method. In addition, we considered linear and exponential forms of OLS. These forms give better predictive estimates when used to estimate demand function (Carreira et al, 2006).

\section{METHODOLOGY}

\section{Study Area}

The study was conducted in southern part of Cross River State because it is the major wetland area in the State. Four local government areas were randomly selected for data collection. They were, Akpabuyo, Odukpani, Akamkpa and Calabar municipality. Stratified sampling technique with simple random selection was adopted in the study. Each local government area was divided into two sub-groups based 
on the location and homogeneity of the wetland. Only farmers that grow cassava, maize and pumpkin in mixture or as a mono cropping system were considered for selection. In each of the sub-groups, 25 farmers were randomly selected in Akpabuyo, a total of 50 farmers were randomly selected from the 2 sub-groups in Odukpani. A total of 20 farmers were randomly selected from Akamkpa and 10 farmers from Calabar Municipality. In all, 130 farmers were used for data collection.

\section{EMPIRICAL MODEL}

Two forms of demand model were used, as they were expected to produce better estimates when used to estimate demand function (Carreira et al 2006). Ordinary Least Square method was used to estimate the selected functional forms.
Linear form:

$$
Y=a_{0}+a_{i} X i+a_{2} X_{2}+a_{3} X_{3}+\ldots+a_{n} X_{n}+e_{1}
$$

Exponential form:

$$
L N Y=a_{0}+a_{i} X i+a_{2} X_{2}+a_{3} X_{3}+\ldots+a_{n} X_{n}+e_{2 \ldots} \text { (5) }
$$

Where e's are white noise or error terms, $X$ 's are vectors of explanatory variables. Details of X's are given below. Note that $Y$ is the quantity of fertilize bought in $\mathrm{N} / \mathrm{kg}$. The models specified, are used to investigate both income and non income determinants of fertilizer demand expressed in $(A / \mathrm{kg})$ by wetland farmers in Cross River State.

\section{DESCRIPTION OF VARIABLES}

Based on previous empirical work, we specify the following variables for investigation in the study area. The variables are listed and described as in Table1 below.

\begin{tabular}{|c|c|c|}
\hline VARIABLE & TYPE & DESCRIPTION \\
\hline AGE & Continuous & Age of a farmer in years \\
\hline HHS & Continuous & House hold size in number \\
\hline SEX & Binary & Sex of respondent; 1 if male and 0 otherwise \\
\hline AGE2 & Continuous & Age of a farmer square in year square \\
\hline EDU & Continuous & Formal education of a farmer in years \\
\hline ETHNICITY & Binary & State of origin of a farmer; 1 for indigenes 0 otherwise \\
\hline FARMSS & Continuous & Farm size of respondent in $\mathrm{A} /$ hectare \\
\hline FARMSS2 & Continuous & Farm size square in $\mathrm{N} /$ hectare square \\
\hline LANDOWN & Binary & Farm ownership: 1 for owner and 0 0therwise \\
\hline CRD & Binary & Farm practice; 1 for mixed cropping and 0 otherwise \\
\hline $\mathrm{DH}$ & Continuous & House - farm distance cost in $\mathrm{N} / \mathrm{Km}$ \\
\hline DP & Continuous & Fertilizer purchase point - farm distance cost in $\mathrm{A} / \mathrm{Km}$ \\
\hline EXS & Continuous & Number of contact with an extension agent \\
\hline MMA & Continuous & Membership of Association in years \\
\hline $\mathrm{HHC}$ & Continuous & House hold consumption expenditure $(\mathbb{N})$ \\
\hline OFI & Continuous & Off-farm income of farmers $(\mathrm{N})$ \\
\hline PFER & Binary & Farmer fertilizer price idea; 1 for high price and 0 otherwise \\
\hline FIN & Continuous & Farm income of a farmer in (AE) (A) \\
\hline $\mathrm{NOPH}$ & Continuous & Number of poultry kept by the farmers \\
\hline $\mathrm{NOGH}$ & & Number of goats kept by the farmers \\
\hline PRF & Binary & Farmer ability to predict rainfall; 1 for yes and 0 otherwise \\
\hline ART & Binary & Access to modern communication; 1 for yes and 0 otherwise \\
\hline FPM & Binary & Soil practice; 1 for bedding and 0 otherwise \\
\hline OMM & Continuous & Output of maize in $\mathrm{A} / \mathrm{kg}$ \\
\hline OCC & Continuous & Output of cassava in $\mathrm{A} / \mathrm{kg}$ \\
\hline OTP & Continuous & Output of pumpkin in $\mathrm{A} / \mathrm{kg}$ \\
\hline MCP & Continuous & Output of maize, cassava and \\
\hline FERT. & Continuous & Quantity of fertilizer purchase by farmer expressed in $\mathrm{A} / \mathrm{kg}$ \\
\hline
\end{tabular}

TABLE 1: VARIABLE DESCRIPTION

Farm income (FIN) is expressed in adult equivalent (AE) $\mathrm{N}$ where

$A E=1+0.7\left(N_{1}-1\right)+0.5\left(N_{2}\right)$ [Quartey (2005) in Ukoha et al ( 2007)].

$\mathrm{N}_{1}=$ Number of adult aged 15 years or above

$\mathrm{N}_{2}=$ Number of children aged less than 15years. Then the farm income per adult equivalent was derived as a total of farm income divided by the adult equivalent (AE). 


\section{RESULTS}

Table 2: SOCIO- ECONOMIC PROFILE OF WETLAND FARMERS

\begin{tabular}{|c|c|c|}
\hline \multirow{5}{*}{$\begin{array}{l}\text { Characteristic } \\
\text { Sex } \\
\text { Male } \\
\text { Female } \\
\text { Total } \\
\end{array}$} & Frequency & Percentage \\
\hline & & \\
\hline & 90 & 69.2 \\
\hline & 40 & 30.8 \\
\hline & 130 & 100.0 \\
\hline \multicolumn{3}{|l|}{ Age (year) } \\
\hline$<20$ & 31 & 23.8 \\
\hline $20-30$ & 40 & 30.8 \\
\hline$>30$ & 59 & 45.4 \\
\hline Total & 130 & 100.0 \\
\hline \multicolumn{3}{|l|}{ Education (year) } \\
\hline No schooling & 4 & 3.0 \\
\hline Primary school & 81 & 62.4 \\
\hline Secondary school & 35 & 26.9 \\
\hline Tertiary & 10 & 7.7 \\
\hline Total & 130 & 100.0 \\
\hline \multicolumn{3}{|l|}{ Family size } \\
\hline$<3$ & 25 & 19.2 \\
\hline $3-5$ & 60 & 46.2 \\
\hline$>5$ & 45 & 34.6 \\
\hline Total & 130 & 100.0 \\
\hline \multicolumn{3}{|l|}{ Extension contact } \\
\hline Zero contact & 83 & 63.9 \\
\hline$>3$ contacts & 29 & 22.3 \\
\hline$>5$ contacts & 18 & 13.8 \\
\hline Total & 130 & 100.0 \\
\hline \multicolumn{3}{|l|}{ Farm income (A) } \\
\hline$<10,000$ & 50 & 38.5 \\
\hline$>10,000$ & 80 & 61.5 \\
\hline TOTAL & 130 & 100.0 \\
\hline FARM Size(Ha) & & 46.2 \\
\hline $0.1-0.3$ & 60 & 53.8 \\
\hline$>0.3$ & 70 & 100.0 \\
\hline Total & 130 & \\
\hline \multicolumn{3}{|c|}{ Membership of association (yr) } \\
\hline$<1$ & 4 & 3.1 \\
\hline $1-10$ & 70 & 53.8 \\
\hline$>10$ & 56 & 43.1 \\
\hline Total & 130 & 100.0 \\
\hline \multicolumn{3}{|c|}{ Farming Experience (yr) } \\
\hline$<2$ & 15 & 11.5 \\
\hline$>2$ & 115 & 88.5 \\
\hline Total & 130 & 100.0 \\
\hline
\end{tabular}

Source: Field survey, 2008

The result from Table 2 reveals that the majority of wetland farmers in Cross River state are males. This perhaps explains the high labour energy required to cultivate a wetland farm. Majority of farmers are relatively of youthful age and have few years of formal education. More than $40 \%$ of the respondents have moderate family size of 3 to 5 members and more than $60 \%$ have zero contact with extension agent. About $90 \%$ of the respondents have farm size less than one hectare and more than $60 \%$ made income of more than $\mathrm{N} 10$, 000 in their farming activities.

\section{DETERMINATIONS OF FERTILIZER DEMAND}

Two functional forms of fertilizer demand function were estimated, namely; the linear and the exponential forms. The Linear form was picked as the lead equation because it exhibits better predictive value, and also contains more significant variables.

For the lead equation, $89.16 \%$ of the variability in fertilizer demand was associated with the specified variables. The F- statistic (3.595) was highly significant at $1 \%$ level. This means the specified multiple linear regression model provides a better estimation to the fertilizer demand function of farmers in the study area. 
TABLE 3: RESULTS OF REGRESSIONS.

\begin{tabular}{|c|c|c|}
\hline VARIABLE & LINEAR (L) & EXPONENTIAL \\
\hline AGE & $-0.395(-0.420)$ & $-0.027(-0.598)$ \\
\hline $\mathrm{HHS}$ & $-0.451(-1.712)^{*}$ & $-0.124(0.816)$ \\
\hline SEX & 15.083(-1.791) & $0.512(0.842)$ \\
\hline AGE2 & $-3.910(-0.820)$ & $-2.83(1.287)$ \\
\hline EDU & $1.821(1.873)^{*}$ & $-0.115(1.758)^{*}$ \\
\hline ETHNICITY & $18.995(1.541)$ & $1.064(1.912)^{*}$ \\
\hline FARMSS & $19.354(9.490)^{* * *}$ & $0.335(0.344)$ \\
\hline FARMSS2 & $-7.502(-7.117)^{\star * *}$ & $-0.209(-0.068)$ \\
\hline LANDOWN & $-8.983(-0.759)$ & $-0.434(-0.764)$ \\
\hline CRD & $4.279(0.244)$ & $-0.073(-0.087)$ \\
\hline $\mathrm{DH}$ & $-1.175(-0.539)$ & $0.015(0.140)$ \\
\hline DP & $-0.029(-0.480)$ & $-0.001(0.404)$ \\
\hline EXS & $2.062(1.967)^{*}$ & $0.398(0.551)$ \\
\hline MMA & $1.156(0.808)$ & $0.049(0.715$ \\
\hline $\mathrm{HHC}$ & $-3.230(1.712)^{*}$ & $0.000015(1.690)^{*}$ \\
\hline OFI & $0.001(0.689)$ & $0.000089(1.914)^{*}$ \\
\hline FIN & $0.0007(2.896)^{* *}$ & $0.0000007(0.300)$ \\
\hline $\mathrm{NOPH}$ & $-0.081(-1.615)^{*}$ & $-0.022(1.269)$ \\
\hline NOGP & $-0.711(-1.710)^{*}$ & $-0.12(1.970)^{*}$ \\
\hline PRF & $9.936(8.800)^{* * *}$ & $0.759(1.410)$ \\
\hline ART & $17.859(2.113)^{\star *}$ & $1.3414(1.705)^{\star}$ \\
\hline FPM & $9.949(0.508)$ & $0.855(0.908)$ \\
\hline OMM & $1.66(1.799)^{*}$ & $-0.003(-0.057)$ \\
\hline OCC & $-0.096(-0.047)$ & $-0.018(-0.184)$ \\
\hline OTP & $-0.530(-0.562)$ & $-0.010(-0.254)$ \\
\hline MCP & $0.003(1.696)^{*}$ & $-00011(-1.401)$ \\
\hline PFER & $-0.913(-.7 .130)^{* * *}$ & $-0.193(-3.510)^{* * *}$ \\
\hline CONSTANT & $3.648(1.500)$ & $0.799(1.200)$ \\
\hline $\mathrm{R}^{2}$ & 0.891 & 69.91 \\
\hline$-R^{2}$ & 0.776 & 62.73 \\
\hline F-STAT & $3.595^{\star \star \star}$ & $3.012^{* \star \star}$ \\
\hline
\end{tabular}

Note: ${ }^{*},{ }^{* *}$, and ${ }^{* * *}$ represent significant at the $10 \%, 5 \%$ and 1 percent $(\%)$ levels respectively. Variables are as defined in Table 1 . Value in parenthesis is t-ratio. $L=$ lead equation.

Household size has a negative significant (at $10 \%$ significance level) effect on fertilizer demand by wetland farmers. This suggests that as household size increases, more of the household income is channelled to household expenditure rather than to investment in buying fertilizer.

Educational level of the farmer has positive significant (at 10\% significance level) impact on fertilizer demand. This means that as farmer's education levels get higher, the tendency for innovation adoption will also increase. This suggests that farmers will be exposed to current information on soil management as level of education increases. This in turn enhances their fertilizer demand. Steal et al (2008) had reported similar result. Farm size has a strong positive significant (at 1\% significant level) effect on fertilizer demand. Farm Size Square rather shows a negative significant impact. The result implies that total fertilizer demand increases with the farm size but at a decreasing rate. In other words, the unit per hectare demands of fertilizer declines with increase in farm size. Minot et al (2000) had similar result for Benin Republic.
The frequency of contact with an extension agent has positive significant (at $10 \%$ significance level) effect on fertilizer demand. This suggests that frequent extension agent- farmers meeting will promote awareness on the use of fertilizer by farmers. This will improve farmer's fertilizer demand.

The Household consumption expenditure has negative significant (10\% significance level) effect on fertilizer demand by wetland farmers. This result suggests that farmer's fertilizer demand decreases with increased household consumption expenditure. This means that farmers prefer satisfying their domestic food demand to purchasing fertilizer.

Farm income, farmer ability to predict rainfall, and access to communication facilities have a positive significant (at $5 \%, 10 \%$ and $5 \%$ significance levels respectively) effect on fertilizer demand. As farm income increases, farmer's fertilizer demand also increases. Ability to predict rainfall affects positively the quantity of fertilizer used by the farmers. Also, the presence of modern communication facilities enhances fertilizer usage by the farmers. This actually reduces transportation cost and other variable costs. The 
numbers of poultry birds and goats kept by the wetland farmers have a negative significant (at 10\% significance level each) effect on fertilizer demand. The poultry litter and the animal dunes are good supplement to mineral fertilizer. The more the farmers have access to this manure sources, the more they reduce the consumption of fertilizer. Perhaps due to excessive deterioration of the wetland soil, the magnitude of the effect is relatively small; each manure source reduces fertilizer demand by less than $1 \mathrm{~kg}$ per hectare.

The output of maize crop has a positive significant (at $10 \%$ significance level) response to fertilizer demand. The result reveals that maize crop responded better to fertilizer application than other crops in the wetland area. The result suggests that, farmers that planted maize have high demand for fertilizer than other crops. In other words, a farmer that plants maize crop is likely to increase fertilizer demand by $1.66 \mathrm{~kg}$ per hectare. Minot et al (2000) obtained similar result in Malawi. Combined output of cassava, maize and pumpkin has positive significant (at 10\% significance level) response to fertilizer demand. The maize content perhaps increases the fertilizer usage or demand.

\section{CONCLUSION AND POLICY IMPLICATION}

The study examined the socio-economic profile of the wetland farmers in Cross River State and identified the factors that affect fertilizer demand among the farmers. The study reveals that male farmers predominate the farming activities in the region. Majority of the farmers were of youthful age and had up to primary school education. Majority of respondents have 3 to 5 family size and zero contact with the extension agent while few made farm income less than $\$ 10,000$ and had farm size greater than 0.9 hectare.

On the other hand, the results of the regression indicate that household size, farm size square, household consumption, number of poultry birds, numbers of goats and farmer idea on fertilizer price have negative influence on farm level demand of fertilizer by wetland farmers. On the other hand, education of the farmer, farm size, extension service, farmer's ability to predict rainfall and output of maize have positive significant effect on fertilizer demand by the farmers. Based on the above results, we propose the following policy implications and recommendations.

$>$ Policies, which reduce production constraints and household size, will increase wetland farmer's ability to increase fertilizer consumption. A reduction in agricultural production constraint will increase farm income through reduction in variable cost and subsequent increase in farm total revenue. Additionally, it will increase the number of farm plot, which has a positive significant effect on fertilizer demand.

$>$ Education of the farmer and extension service have positive significant effect on farmers. Thus policies that are geared towards educational development of the rural people in Cross River State will also promote awareness on the use of fertilizer through exposure of the rural farmers to current information on soil management techniques. Such policies will promote fertilizer demand among the farmers and are therefore strongly advocated.

$>$ Farmer's ability to predict rainfall and access to modern communication facilities have positive significant influence on fertilizer demand. The result suggests that policies that are aimed towards rural development through provision of amenities and infrastructures such as metrological centre and modern global system of communication facilities will improve fertilizer demand. This is based on the premise that, farmers will reduce costs, risks and uncertainty while channelling the unspent or saved income to fertilizer purchase.

$>$ Manure-fertilizer research programme should be set-up by institutions, NGO's, individual and government. The aim should include modality for optimum combination of manure and fertilizer inputs to achieve economic yield while maintaining soil fertility and sustainable environmental impact. This will promote fertilizer and manure demand as a complementary productivity enhancing input in the state.

$>$ Maize output has a positive significant impact on fertilizer demand. The result suggests that farmers in the wetland region of the state should incorporate maize as one of their major crops as this will lead to increased fertilizer demand.

\section{REFERENCES}

Abdulahi, A., 1999. Food Policy and Food Security in Nigeria. Proceeding of methodology and stockholders workshop. 7-8 Sept. 1999, Kaduna State, Nigeria.

Awosika, L. F., Osuntogun, N. C., Oyewo, E. O. and Awobamise, A., 2001. Development, protection of coastal and marine Environment in SubSaharan Africa. Reports of Nigeria Integrated problem Analysis.

Awosika. L. F. and Awobasmise, A., 2001b. Report of the Nigerian Integrated Problem Analysis on Development and Protection of the Coastal and Marine Environment in Sub-Saharan Africa 15, $16 \mathrm{pp}$.

Byerlee, D., and Eicher, C. K. eds., 1997. Africa's Emerging Maize Revolution. Boulder, CO: Lynne Rienner Publishers.

Carreira, R. I. and Goodwin, H. L., 2006. Estimating demand function for Poultry Litter. A paper presented at the American Agricultural Economics Association Annual meeting, Long Beach California USA.

Croppenstedt, A. and Demeke, M., 1996. Determinants of adoption and Levels of demand for fertilizer for cereal growing farmers in Ethiopia. Working 
Paper No. 96-3 Centre for the Study of African Economies, Oxford University, Oxford.

Daramola, B., 1989. The study of socio economics factors influencing fertilizer adoption decision in Nigeria. A survey of Oyo State farmers. Fertilizer research 20: 143-151.

Falusi, A. O., 2008. Sustainable Agriculture in SubSaharan Africa. A critical look into constraints and prospects; Being paper presented at IARSAF Conference, IITA, Ibadan.

FAO., 2004a. Fertilizer Development in Support of the Comprehensive Africa Agriculture Development Programme (CAADP). Paper presented at FAO Twenty-third regional conferences for Africa, 15 March, Johannesburg, South Africa.

FAO., 2004b. Increasing fertilizer use and farmer access in sub-Saharan Africa. A literature Review. Draft. Agricultural Management, Marketing and Finance Service (AGSF), Agricultural Support Systems Division, Rome. Feder, Gershon, and Roger Slade. 1984. "The Acquisition of Information.

Fufu, B. and R. M., 2006. Determinants of fertilizer use in maize in Eastern Ethiopia. A weighted endogenous sampling Analysis of the extent and intensity of adoption. Agrekon, vol. 45 no. 1

Gruhn, P., Goletti, F. and Yudelman., M., 2000. Integrated Nutrient Management, Soil Fertility, and Sustainable Agriculture: Current Issues and Future Challenges.

Heisey, P. W. and Wilfred, M., 1996. Fertilizer use and Maize production in Sub-Saharan Africa. CIMMYT Economics working paper 96-01. Mexico, D. F. CIMMYT.

Kelly, V. A., 2006. Factors affecting demand for fertilizer in Sub-Saharan Africa. A report submitted to World Bank.
Lawal, A. M and Omotesho, O. A., 2008. Cereals and farming household food security in Kwara state, Nigeria. Medwell journal 3(3): 235-240.

Minot, N., Mylene, k. and Philippe B., 2000. Fertilizer market Reform and determinants of fertilizer use In Benin and Malawi. International Food Policy Research Institute US.

Naseem, A. and Valerie, K., 1999. Macro trends and Determinants of Fertilizer use in Sub-Saharan Africa. MSU international Dev. Paper US.

Nwosu, A. C., 1995. Fertilizer supply and distribution policy in Nigeria. Sustainable Agriculture and Economic Development in Nigeria. Morrilton, Arkawe Winrock.

Okunneye, P. A., 2003. Rising cost of food prices and food insecurity in Nigeria and its implication for poverty reduction. CBN Economic and Financial Reviw. 93(4).

Staal, S. J., Rommey, D., Baltenick, I., Waithaka, M., Muriuk, H. and Njoroge, L., 2003. Spatial Analysis of soil fertility management using Integrated Household and GIS data from smallholder Kenyan farms. International Livestock Research Institute Kenya.

Smith, J., Barau, A. D., Goldman, A. and Mareck, J. H., 1994. The role of technology in agricultural intensification: The evolution of maize production in the northern Guinea savanna of Nigeria. Economic Development and Cultural Change 42(3): 537-554.

Ukoha, O. O., 2005. Relative price variability and inflation; Evidence from Agricultural Sector in Nigeria. African Economic Research Consortium, Kenya.

Uwatt, B. U., 1997. Technology, Agricultural productivity and food security in Akwa- Ibom State Nigeria. Interim Report ARSSRAN, Winrock Internationa, USA. 